Texas A\&M University-San Antonio

Digital Commons @ Texas A\&M University- San Antonio

\title{
Humble Coaches and Their Influence on Players and Teams: The Mediating Role of Affect-Based (but Not Cognition-Based) Trust
}

\author{
Ho Phi Huynh \\ Texas A\&M University-San Antonio, Ho.Huynh@tamusa.edu \\ Clint E. Johnson \\ Georgia Southern University \\ Hillary Wehe \\ Davis \& Elkins College
}

Follow this and additional works at: https://digitalcommons.tamusa.edu/psyc_faculty

Part of the Social Psychology Commons

\section{Repository Citation}

Huynh, Ho Phi; Johnson, Clint E.; and Wehe, Hillary, "Humble Coaches and Their Influence on Players and Teams: The Mediating Role of Affect-Based (but Not Cognition-Based) Trust" (2019). Psychology Faculty Publications. 1.

https://digitalcommons.tamusa.edu/psyc_faculty/1

This Article is brought to you for free and open access by the College of Arts and Sciences at Digital Commons @ Texas A\&M University- San Antonio. It has been accepted for inclusion in Psychology Faculty Publications by an authorized administrator of Digital Commons @ Texas A\&M University- San Antonio. For more information, please contact deirdre.mcdonald@tamusa.edu. 


\begin{abstract}
Humility is a desirable quality for leaders across different domains, but not much is known about humility in sports coaches. This study integrated positive and organisational psychology to define humility as it pertains to sports coaches and examined humble coaches' influence on player development and team climate. Additionally, trust was examined as a mediator between coaches' humility and the two outcomes. Participants $\left(N=184 ; M_{\text {age }}=23.44, S D_{\text {age }}=8.69\right.$; $73.4 \%$ women) rated their coaches' humility and reflected on the coaches' influence and their team climate. Results indicated that affect-based, but not cognition-based, trust mediated the relationship between humility and coaches' influence on players and team climate. Theoretical and practical implications for sports coaches are discussed.
\end{abstract}

Keywords: Humility; Coaching; Trust; Team Climate; Influence; 
Humble Coaches and their Influence on Players and Teams:

The Mediating Role of Affect-Based (but not Cognition-Based) Trust

"Talent is god given. Be humble. Fame is man-given. Be grateful. Conceit is self-given.

Be careful." - John Wooden

Whether striving to be a leader in medicine or business, humility appears to be a desirable quality (Ruberton et al., 2016; Owens \& Hekman, 2016). In sports, humility is a celebrated characteristic among successful coaches, such as the legendary basketball coach John Wooden (Perez, Van Horn, \& Otten, 2014). However, only anecdotal evidence exists to support the effectiveness of humble coaches. The literature lacks a conceptualization of the humble coach, provides no specific outcomes associated with their humility, and offers no mechanism to explain humility's influence on players and teams. In this study, we integrated positive and organisational psychology to define humility as it pertains to sports coaches (Cannon-Bowers \& Bowers, 2006). Moreover, we examined two specific outcomes of humble coaches: their influence on player development and team climate. Additionally, we examined trust as a mediator for humility and coaches' influence on player development and team climate.

\section{Humility}

Humility has not always held status as a virtue (Wright et al., 2016). For example, it has been tied to incompetence, vulnerability, and low self-esteem (Emmons, 1999; Peterson \& Seligman, 2004; Tangney, 2000). However, as researchers refined humility's definition and made its measurement more precise (Davis et al., 2011), they began to uncover its true potential as a virtue. Today, ample evidence exists to support humility's positive relationships with psychological and physical health, prosocial behaviours, and quality interpersonal relationships (Chancellor \& Lyubomirksy, 2013; Davis et al., 2013; Exline \& Hill, 2012; Jankowski, Sandage, 
\& Hill, 2013; Krause, 2010; Krause, Pargament, Hill, \& Ironson, 2016; LaBouff et al., 2012). In the following, we review humility's definition and propose how sports coaches can exhibit humility accordingly. We cite evidence from general humility research to guide the extension of humility to sports coaches. We also summarize methodological challenges related to measuring humility.

Although various definitions of humility exist, researchers generally agree that humility in a stable quality, which has both intrapersonal and relational components (Chancellor \& Lyubomirksy, 2013; Peterson \& Seligman, 2004; for state approach see: Kruse, Chancellor, \& Lyuomirsky, 2017). In terms of intrapersonal dynamics, humble people tend have a secure, accepting identity (Tangney, 2000), freedom from distortion (Baumeister, Bratslavsky, Finkenauer, \& Vohs, 2001), and openness to new information (Stangor \& Thompson, 2002). In terms of interpersonal relations, humble people tend to be other-focused and hold egalitarian beliefs (Chancellor \& Lyubomirksy, 2013).

Accordingly, humble coaches may possess a calm, secure, and accepting identity that is not hypersensitive to ego threats, such as a loss from competition (Peterson \& Seligman, 2004; Tangney, 2000). Their self-impressions are clear, internally consistent, and stable. Coaches may be less concerned with social comparisons and self-evaluations, instead choosing to be kind to one's self (Neff, Kirkpatrick, \& Rude, 2007). Through this conceptualization, coaches embrace the present, and understand that different struggles are experienced broadly by all individuals. This may allow them to buffer the effects of negative, self-relevant events and reduce anxiety (Kesebir, 2014).

Consistent with a stable identity, humble coaches' self-view may be more accurate and free from distortion. They can accurately manage self-relevant information, clearly assess their 
strengths and weaknesses, and accept responsibility for their errors without the need for selfenhancing or self-debasing behavior (Tangney, 2000). Therefore, humility may allow coaches to accept self-limitations and manage information directed at the self without the need to enhance or uphold unrealistically high or low self-views (Baumeister et al., 2001; Tangney, 2000). This may lead coaches to accept responsibility for negative events with less malice and lower negative affect (Leary et al., 2007).

Humble coaches are likely to be open to new information that might offer insights about one's self and the world (Chancellor \& Lyubomirksy, 2013). They seek the truth and knowledge even in potentially embarrassing situations. This motivation is driven by the want of learning rather than the fear of failure (Diseth, 2003). This outlook empowers coaches to learn from others who are different, thus reducing favouritism and social categorization, as well as clearly analysing alternative viewpoints without distortion or prejudice (Stangor \& Thompson, 2002).

Consistent with the idea that humility has internal and relational components, humility may also influence coaches' interactions with others (e.g., players, staff). Humble coaches may display a lack of self-focus, thereby increasing awareness and appreciation for others. The ability to empathize and sympathize with other people can create a stronger social community with positive social outcomes (Chancellor \& Luybomirsky, 2013). Indeed, this other-focus orientation creates a collective-promotion focus whereby a group is able reach its full potential (Owens \& Hekman, 2016). This concern for others can be expressed in a number of ways including forgiveness (Shepherd \& Belicki, 2008), helpfulness (LaBouff et al., 2012), and generosity (Exline \& Hill, 2012).

Finally, coaches' interactions with others may demonstrate their egalitarian beliefs. They see others as having the same intrinsic value as themselves (Tangney, 2000). Therefore, they 
share available resources and treat others equally and fairly (Hilbig \& Zettler, 2009). They tend to be more communitarian and cooperative than individualistic and competitive, regardless of consequence or expectation (Riyanto \& Zhan, 2014).

There are unique challenges to measuring humility. For example, implicit measures of humility are available, but they can have unreliable construct validity (Davis et al., 2010; Rowatt et al., 2006). Alternatively, self-report measures (e.g., HEXACO, Lee \& Ashton, 2004) create a dilemma in which a truly humble person is not likely to portray themselves as humble, seeing their recitation of achievement as prideful or boasting (an exception may be an indirect selfreport measure of state humility, see Kruse et al., 2017). A relational approach may be the best strategy overcome the self-report limitations associated with measuring the stable display humility (Davis et al., 2011; Landrum, 2011; Cohen et al., 2013). That is, instead of asking coaches to rate their own humility, it may be more prudent to ask their players to rate their coaches' level of humility (Funder, 1995; Kenny et al., 1994).

\section{Outcomes of Coaches' Humility}

We propose that when coaches are humble, they can serve as a positive influence on their player's whole-person development including athletic, academic, and personal success. In addition, humble coaches create a positive team climate in which players have room to prosper.

Influence on Player Development. Coaches are in a position to influence their players' athletic, academic, and personal development. The main expectation is that coaches influence their players' athletic development (Iso-Ahola, 1995). Effective coaches teach proper technical skills and strengthen players' psychological preparedness to increase their rate of success (Smith et al., 2007). They influence their players' training motivation (Goose, \& Winter, 2012). Coaches also ensure their athletes are at peak physical condition to meet the demands of competition and 
create a safe and productive recovery process to ensure players successfully return from injury (Fernandes et al., 2014). In addition to their influence on athletic development, coaches can influence their players' academic development. For example, coaches can set high expectations for academic performance and affect academic behaviours such as class attendance (Martens et al., 2006). Coaches can also be instrumental in their players' personal development by affecting their players' health behaviours and through deterring them from engaging in harmful behaviours, such as excessive alcohol consumption (Mastroleo et al., 2012). Moreover, coaches can have long-term impacts by positively influencing players' value orientation (Kemper, 1968) and career pursuits (Snyder, 1972).

Team climate. Beyond engaging their players on an individual level, effective coaches also create a positive team climate, which represents team members' perceptions of the group's norms, attitudes, and motivations (e.g., Anderson \& West, 1998; Burch \& Anderson, 2003; Kim \& Cruz, 2016; Pirola-Merlo et al., 2002). When there is a productive team climate, team cohesion is increased, which leads to athletes becoming more self-motivated, more dedicated to their team, sport, and success (Carron, Bray, \& Eys, 2002; Turman, 2003). Furthermore, research demonstrated that players are more satisfied with coaches who create high team cohesion, even when controlling for the effect of player-leaders on the team (Fransen, Decroos, Vande Broek, \& Boen, 2016). On the other hand, when teams face decreased cohesion, team members tend to be fearful of inequity, embarrassment, and ridicule (Keegan et al., 2011). Team climate may also influence creativity and innovation (e.g., Hulsheger et al., 2009; Somech \& Drach-Zahavy, 2013).

\section{Trust as a Mechanism}


Research and anecdotal evidence support sports coaches' potential for influencing player development and team climate. However, for humble coaches, the path to these outcomes may be different. We propose that humble coaches positively influence their players and create a cohesive team climate because they effectively gain players' trust (Ergeneli, Sa, Ari, \& Meti, 2007; Williams, 2007). Coaches can build trust through their competence and responsibility or by creating emotional bonds with players (McAllister, 1995). That is, coaches can develop cognition-based or affect-based trust (Chua et al., 2008; Schaubroeck et al., 2011).

Cognition-based trust relies on a rational and effortful process in which players make decisions about whether to trust their coach based on the coach's skills and abilities (McAllister, 1995). Therefore, cognition-based trust is usually situation-specific; players must incorporate evidence of trustworthiness from individual circumstances they encounter (Gian et al., 2012; Okhuysen \& Bechky, 2009). Ultimately, if a player finds enough evidence or "good reasons" to trust the coach, then he or she will do so.

In addition to cognition-based, coaches can build affect-based trust with their players. Affect-based trust forms when a coach expresses genuine concern for the well-being of their players and invests in and intrinsically values relationships with their players (Chua et al., 2008; McAllister, 1995; Schaubroeck et al., 2011). Both the player and coach feel that these emotional ties are mutual (Gian et al., 2012; Williams, 2007). Unlike cognition-based trust, which is more superficially contingent on the coaches' merits and qualifications, affect-based trust uniquely depends on faith and emotional trustworthiness. This faith requires players to make greater time and emotional investments as compared to competency-based evaluations. Affect-based trust may be easier for humble coaches to cultivate because humble people tend exhibit prosocial 
behaviours such as helpfulness (LaBouff et al., 2012) and willingness to forgive others (Rowatt et al., 2006), which enable them to form more quality interpersonal relationships.

\section{Summary of Proposed Model and Hypotheses}

Humility is a desired virtue for leaders generally, but it is unclear how sports coaches can be humble and how coaches' humility affects players and teams. We propose that humble coaches influence their players personally, academically, and athletically and humble coaches build a conducive team climate. Moreover, we propose that humility operates through trust, especially affect-based trust. That is, humble coaches build trusting relationships with their players by creating deep emotional bonds and, in the process, coaches can become more influential and establish a productive team climate. Therefore, we hypothesize that:

- Hypothesis 1: Affect-based, but not cognition-based, trust mediates the relationship between coaches' humility and players' perceptions of their coaches' general influence.

- Hypothesis 2: Affect-based, but not cognition-based, trust mediates the relationship between coaches' humility and players' perceptions of their team climate.

\section{Method}

\section{Participants}

Undergraduate students completed an online survey to earn research participation for their introduction to psychology class or to earn extra credit for other psychology courses. These are general undergraduate students (i.e., we did not specifically recruit student-athletes at the university). Participants answered a series of demographic questions and then they indicated whether they have participated in an organized sport. Only participants who responded yes were included in this study $\left(N=184 ; M_{\text {age }}=23.44, S D_{\text {age }}=8.69 ; 73.4 \%\right.$ women; $71 \%$ 
White/Caucasian, $17 \%$ Black/African American, 8\% identified with more than one option, 3\% Asian, and $1 \%$ preferred not to say/other).

Participants focused on the most recent organized sports experience and the corresponding coach. If a participant stated that he or she was currently playing on an organized sports team (4\% of total), they were asked to focus on this coach and team while responding to the survey.

\section{Measures}

Athletic experience, coach, and team. Participants indicated how many years they have participated in organized sports $(M=6.97, S D=5.10)$, how many years it has been since they participated in organized sports $(M=3.55, S D=1.67)$, and what sport it was $(18 \%$ soccer, $11 \%$ softball, $10 \%$ basketball, $9 \%$ volleyball, $7 \%$ tennis, $7 \%$ cheer, $5 \%$ baseball, $~ 3 \%$ each for football, gymnastics, lacrosse, swim, track and field, other listed sports, include bowling, cross country, field hockey, shooting, skiing, ultimate Frisbee [all less than 2\%]). They also provided the coach's gender (36\% female), how many years they played for this coach $(M=3.46, S D=$ 3.15), and their perception of the team's success (“Compared to other teams, how successful was your team?” 1 [not very successful], 7 [extremely successful]; $M=4.95, S D=1.27$ ). Additionally, participants answered questions about their coach's humility, overall influence, team climate, and trust.

Relational Humility. Participants rated their coaches' humility by completing the 5-item Global Humility subscale of the Relational Humility Scale (Davis et al., 2011). Sample questions include: "This coach has a humble character" and "Most people would consider this coach a humble person.” Items were rated using a 5-point Likert scale from 1 (strongly disagree) to 5 
(strongly agree). The scale produced a high level of internal consistency $(\alpha=.96, M=3.52, S D$ $=1.14)$.

Coach's Influence. Coaches' influence on their players was measured using three facevalid items. "How influential was this coach... 1) to your personal development? 2) to your athletic development? 3) to your academic development?" Items were rated using a 7-point Likert scale from 1 (Not at all influential) to 7 (highly influential). Because responses to these three items correlated strongly to each other, we combined the three items to produce a holistic measure of coaches' overall influence on player development. Not surprisingly, the items produced a high level of internal consistency $(\alpha=.83, M=4.24, S D=1.66)$.

Team Climate. Players' perception of their team climate was measured using the 11item Team Climate Inventory (Anderson \& West, 1998). Sample items include: "To what extent are the members of your team critical of new ideas? [R]"; "How supportive are the other members of your team?"; "To what extent do you feel at ease with the members of your team?" Items were rated using a 5-point Likert scale from 1 (a very little extent) to 5 (a very great extent). The scale produced a high level of internal consistency $(\alpha=.85, M=3.74, S D=.71)$.

Affect- and Cognition-based Trust. The two dimensions of trust were measured using McAllister's (1995) scale. Participants indicated their agreement on a scale from 1 (strongly disagree) to 7 (strongly agree). Affect-based trust was measured using a five-item subscale ( $\alpha=$ $.92, M=4.77, S D=1.67)$. Sample items include: "We have a sharing relationship. We can both freely share our ideas, feelings, and hopes."; "If I shared my problems with this coach, I know (s)he would respond constructively and caringly."; "I would have to say that we have both made considerable emotional investments in our working relationship." 
Cognition-based trust was measured using a six-item subscale $(\alpha=.89, M=5.29, S D=$ 1.34). Sample items include: "This coach approaches his/her job with professionalism and dedication."; "Given this coach's track record, I see no reason to doubt his/her competence and preparation for the job."; "Most people, even those who aren't close friends of this coach, trust and respect him/her as a coach."

\section{Results}

\section{Assumptions and Preliminary Analyses}

We examined the main assumptions for multiple regression prior to conducting the analyses. There were no univariate outliers (all $z$-scores were below +/- 3.29; Martin \& Bridgmon, 2012) and there were no multivariate outliers (all Mahalanobis distance scores were below the critical Chi-Square value of 20.51, $d f=5, \alpha=.001$; Tabachick $\&$ Fidell, 2007). The highest variance inflation factor (VIF) value was 1.35 , which is lower than the conservative benchmark of 5, suggesting that collinearity was not an issue. Additionally, the histogram of standardized residuals supported a symmetrical pattern that is within a normal distribution outline. The P-P plot further supported the normality assumption. Finally, the residual scatter plot provided added support for normality, linearity, in addition to homoscedasticity.

Assured that no assumptions were violated, a multiple regression analysis was performed to examine the relationship between participants' gender, coaches' gender, and the variables of interest: ratings of humility, affect-based trust, cognition-based trust, overall influence, relationship length with coach, team success, and team climate. The results did not support a significant relationship between the predicting variables and the outcome variables of interest, $F(7,125)=.65, p=.71$. For the main variables of interest, the effect of participants' gender $(b=$ $.11, S E=.25, t=.45, p=.65)$ and coaches' gender $(b=.11, S E=.25, t=.45, p=.65)$ did not 
significantly predict humility ratings nor did participants' gender $(b=.11, S E=.36, t=.31, p=$ $.74)$ and coaches' gender $(b=-.08, S E=1.2, t=-.07, p=.95)$ significantly predict affect-based trust. This suggests that the impact of humility does not depend on the athlete's or the coach's gender. See Table 1 for bivariate correlations between the variables of interest.

\section{Main Analyses}

Multiple regression analyses were conducted to assess each component of the proposed mediation model that affect-based and not cognition-based trust mediates the relationship between coaches' humility and coaches' overall influence. The results supported a significant connection between the variables of interest, $F(5,149)=29.01, p<.0001, R^{2}=.49$. Controlling for team success, $b=.32, t(153)=3.87, p<.001$, and relationship length between player and coach, $b=.02, t(153)=.72, p=.47$, we found that coaches' humility was positively associated with coaches' overall influence, $b=.68, t(153)=7.22, p<.001$. We also found that coaches' humility was positively related to affect-based trust, $b=1.00, t(153)=12.53, p<.001$, and cognition-based trust, $b=.86, t(153)=10.49, p<.001$. Lastly, results indicated that affect-based trust was positively associated with coaches' overall influence, $b=.43, t(153)=4.06, p<.001$, but cognition-based trust was not associated with coaches' overall influence, $b=.04, t(153)=$ $.48, p=.63$. Mediation analyses were tested using the bootstrapping method with bias-corrected confidence estimates (MacKinnon, Lockwood, \& Williams, 2004; Preacher \& Hayes, 2004). Although the path from cognition-based trust to coaches' influence is not significant, that fact is immaterial under the current mediation analysis method (Hayes, 2009). Moreover, it is important to test affect-based trust as a mediator while controlling for the effects of cognition-based trust; therefore, we continued to test cognition-based trust as a mediator. In the present study, the $95 \%$ confidence interval of the indirect effects was obtained with 5000 bootstrap resamples (Preacher 
\& Hayes, 2008). Results of the mediation analysis confirmed the mediating role of affect-based trust in the relation between coaches' humility and their overall influence, $b=.43, C I[.23, .68]$. On the other hand, cognition-based trust was found to not mediate the relation between coaches' humility and their overall influence, $b=.04, C I[-.14, .24]$. In addition, results indicated that the direct effect of humility on overall influence became non-significant, $b=.20, t(153)=1.58, p=$ .12 , when controlling for affect- and cognition-based trust, thus suggesting full mediation. Figure 1 displays the results.

Similar multiple regression analyses were conducted with team climate as the outcome. The results showed a significant relationship between the variables of interest, $F(5,146)=17.14$, $p<.0001, R^{2}=.37$. Controlling for team success, $b=.22, t(150)=5.44, \mathrm{p}<.001$, and relationship length between player and coach, $b=.02, t(150)=1.37, p=.17$, we found that coaches' humility was positively associated with team climate, $b=.13, t(150)=2.88, p=.004$. We also found that coaches' humility was positively related to affect-based trust, $b=1.00, t(150)$ $=12.56, p<.001$, and cognition-based trust, $b=.86, t(153)=10.49, p<.001$. Lastly, results indicated that affect-based trust was positively associated with team climate, $b=.19, t(150)=$ $3.40, p<.001$, but cognition-based trust was not associated with team climate, $b=-.01, t(150)=$ $-.22, p=.82$. Results of the mediation analysis confirmed the mediating role of affect-based trust in the relationship between coaches' humility and team climate, $b=.19, C I[.07, .29]$. On the other hand, cognition-based trust was found to not mediate the relationship between coaches' humility and team climate, $b=-.01, C I[-.13, .10]$. In addition, results indicated that the direct effect of humility on team climate became non-significant, $b=-.04, t(150)=-.65, p=.52$, when controlling for affect- and cognition-based trust, thus suggesting full mediation. Figure 2 displays the results. 


\section{Discussion}

Although anecdotal experience suggests that humble coaches are effective and desired, empirical evidence is needed to address how coaches' humility may engender a productive team climate and enable coaches to influence their athletes. Our findings confirm our hypotheses that affect-based, and not cognition-based, trust mediates the relationship between coaches' humility and their overall influence on athletes' development and team climate. These findings are congruent with the literature on humility and trust.

When coaches display humility, they display a secure accepting identity, a self-view that is free from distortion, and an openness to new information. Humility also affects how they form relationships with others (Chancellor \& Lyubomirksy, 2013). Humble coaches may tend to focus on other people's needs and view others as equals. When coaches successfully manage their own identity and interactions with players, they are more likely to form affect-based relationships with their players. This outcome has intuitive appeal given that affect-based trust forms from mutual faith and emotional bonds, whereas cognition-based trust relies on perceptions of competence, responsibility, reliability and dependability (McAllister, 1995; Schaubroeck et al., 2011). When players attempt to determine how much trust to place in their coach, they may assess the coach's competency by reviewing the coach's prior record of accomplishment; however, this evidence may not directly involve their participation. For example, a player may cognitively view their coach as successful because their coach has a winning record with a different team or different players, yet despite such success, the player may fail to envision how the prior success directly translates to their own goals or motivations. Conversely, when coaches focus on their players' needs, treat them as partners in the process, and are open to new information, players can bond more easily with their coaches and can understand how their 
coach can personally influence them. Clearly, affect-based trust requires more time and investment than cognition-based trust (McAllister, 1995; Schaubroeck et al., 2011), but this aligns with the nature of humility, which requires a steady and patient approach and disposition.

Additionally, when humble coaches open themselves to new information and have an accurate self-view, they may recognize and acknowledge instances where they are wrong (Chancellor \& Lyubomirksy, 2013). When this occurs, they open themselves up for verdicts about their competence, which may negatively affect their ability to form cognition-based trust. However, this act may further reinforce affect-based trust in their players by displaying their vulnerability and egalitarian beliefs_ - just as players can be wrong, so can their coach.

Through affect-based trust, humble coaches can instil their influence on their players' overall development (i.e., athletic, academic, and personal). Whereas cognition-based trust is domain specific (e.g., sports), affect-based trust can influence areas beyond the player's athletic achievements. Players may feel that their coaches care about them beyond their ability to perform on the court or field if they share a mutual emotional bond. As a result, they may seek advice from their coach and allow their coach to influence their lives in areas outside of athletics. Alternatively, if athletes' trust of their coach is solely based on competence, players may not easily think of their coach as an expert in other areas of need, which may prevent players from seeking advice from their coaches. This failure may ultimately limit how much influence their coach possesses.

In addition, when affect-based trust is earned, players not only benefit on an individual basis but it may translate to a better team climate. Humble coaches may be able to disarm some of the negative influences that characterize the competitive culture of athletics by forming affectbased trust with their players (Chan et al., 2004). For example, when humble coaches form 
affect-based relationships, they increase a sense of equity amongst players because players may view themselves and their teammates as equals instead of looking to establish dominance and enforce a hierarchy. In addition, when players have an emotionally trusting relationship with their coaches, they may be more tolerant of their teammates' mistakes and errors, and less likely to embarrass and ridicule, which ultimately improves team cohesion (Turman, 2003).

\section{Limitations and Future Directions}

We sought to examine humble coaches' influence on their players. Thus, we broadly operationalized influence as players' self-report of athletic, academic, and personal influence. Because of the broad definition, it may be difficult to specifically identify how humble coaches affect appreciable change in their players. We believe that this holistic reflection by players has its merits in capturing players' overall assessment of their coach. Nonetheless, future research can complement this broad approach by examining specific outcomes that directly reflect academic influence (e.g., grade point average; Weathington, 2010), personal development (e.g., growth mindset; Flory \& McCaughtry, 2014), and athletic development (e.g., number of matches won, personal athletic awards; Larsen et al., 2013).

Another limitation of the current study arises from the overlap in players' retrospective assessments of their coach's humility and coach's influence on team climate, which potentially creates a common source bias. Because humility is a difficult construct to measure reliably via self-report (Landrum, 2011; Cohen et al., 2013), future research may look to determine the relationship between players' evaluations of their coaches' humility with more objective outcomes such as win percentage (e.g., from archives) or percentage of players who withdraw from participation under a coach's tenure (Rottensteiner, Laakso, Pihlaja, \& Konttinen, 2013). Additionally, future research can use multiple ratings of the same coach to see if current players 
agree about the coach's level of humility. However, when taking this approach, researchers should be careful to model the data appropriately to avoid bias due to nesting effects. Moreover, researchers may also want to ask coaches to rate their own humility and compare it to players' ratings of their coaches' humility. By doing this, researchers can examine whether a player's individual perception of a coach is predictive of the coach's overall humility.

Finally, we attempted to discover mechanisms through which humility operates in order to engender change. Although we found support for affect-based trust as a mediator, our data is correlational in nature. Future research should seek to experimentally manipulate humility (e.g., Davis et al., 2011; Kruse et al., 2017) and potentially manipulate affect- and cognition-based trust to determine causality. Until then, our findings suggest a relationship between humility, trust, and influence and team climate, but the causal arrow remains unclear.

\section{Practical Implications for Coaches}

Findings from this study can empower coaches to value, pursue, and express humility. By being humble, coaches can build stronger emotional bonds with their players and make a lasting impression on their players and teams. Just as leaders are able learn leadership skills (Avolio, 2005) and coaches can benefit from coaching education (MacDonald, Cote, \& Deakin, 2010), it may be possible for coaches to engage in practices that can help boost their humility. For example, to directly express humility, coaches can practice non-judgmental self-reflection to gauge their own strengths and weakness. They can also seek feedback from their players and staff and display an openness to different opinions and viewpoints. Coaches can also display humility by noting other team members' contributions in instances of success and claim their share of culpability in instances of failures. Additionally, coaches can engage in other practices 
such as expressing gratitude (Kruse et al., 2014) and seeking experiences of awe (Stellar et al., 2017) to increase their humility.

\section{Conclusion}

Although humility is regarded as important for leaders, humility of sports coaches and its outcomes are not well understood. Our study provides evidence to suggest that humble coaches are successful, not merely because of their experience or competence, but because of their ability to build emotional bonds with their athletes. This evidence suggests that humility enables coaches to establish secure, trusting relationships, exert a positive influence on their players, and build a productive team. 


\section{References}

Anderson, N. R., \& West, M. A. (1998). Measuring climate for work group innovation:

Development and validation of the team climate inventory. Journal of Organizational Behavior, 19, 235-258. doi: 10.1002/(SICI)1099-1379(199805)19:3

Avolio, B. (2005). Executive summary: 100 Year review of leadership intervention research: Briefings Report 2004-01, Gallup Leadership Institute. Leadership Review, 5, 7-13.

Baumeister, R. F., Bratslavsky, E., Finkenauer, C., \& Vohs, K. D. (2001). Bad is stronger than good. Review of General Psychology, 5(4), 323-370. doi.org/10.1037/1089-2680.5.4.323

Burch, G. S. J., \& Anderson, N. R. (2003). What does it take to be a good team player? Assessing team climate preference can help. Selection and Development Review, 19(3), 15-19.

Cannon-Bowers, J., \& Bowers, C. (2006). Applying work team results to sports teams: Opportunities and cautions. International Journal of Sport and Exercise Psychology, 4, 447-462. doi.org/10.1080/1612197X.2006.9671807

Carron, A., Bray, S., \& Eys. (2002). Team cohesion and team success in sports. Journal of Sport Sciences, 20, 119-126. doi.org/10.1080/026404102317200828

Chan, L. L., Shaffer, M. A., \& Snape, E. (2004). In search of sustained competitive advantage: The impact of organizational culture, competitive strategy and human resource management practices on firm performance. The International Journal of Human Resource Management, 15(1), 17-35. doi: 10.1080/0958519032000157320

Chancellor, J. \& Lyubomirsky, S. (2013). Humble beginnings: current trends, state prospective, and hallmarks of humility. Social and Personality Psychology Compass, 7(11), 819-83. doi:10.1111/spc3.12069 
Chua, R. Y. J., Ingram, P., \& Morris, M. W. 2008. From the head and the heart: Locating cognition- and affect-based trust in managers' professional networks. Academy of Management Journal, 51, 436-452. doi:10.5465/AMJ.2008.32625956

Cohen, T. R., Panter, A., Turan, N., Morse, L., \& Kim, Y. (2013). Agreement and similarity in self-other perceptions of moral character. Journal of Research in Personality, 47(6), 816830. doi: 10.1016/j.jrp.2013.08.009

Davis, D.E., Hook, J. N., Worthington Jr., E. L., Van Tongeren, D. R., Gartner, A. L., II, D. J., \& Emmons, R. A. (2011). Relational humility: Conceptualizing and measuring humility as a personality judgment. Journal of Personality Assessment, 93(3), 225-234. doi.org/10.1080/00223891.2011.558871

Diseth, A. (2003). Personality and approaches to learning as predictors of academic achievement. European Journal of Personality, 17(2), 143-155. doi:10.1002/per.469

Emmons, R. A. (1999). Religion in the psychology of personality: An introduction. Journal of Personality, 67(6), 873-888. doi:10.1111/1467-6494.00076

Ergeneli, A., Sag, G., Ari, I., \& Metin, S. 2007. Psychological empowerment and its relationship to trust in immediate managers. Journal of Business Research, 60, 41-56. doi: 10.1016/j.jbusres.2006.09.012

Exline, J. J., \& Hill, P. C. (2012). Humility: A consistent and robust predictor of generosity. Journal of Positive Psychology, 7(3), 208. doi: 10.1080/17439760.2012.671348

Fernandes, H. M., Reis, V. M., Vilaça-Alves, J., Saavedra, F., Aidar, F. J., \& Brustad, R. (2014). Social support and sport injury recovery: An overview of empirical findings and practical implications. Revista de Psicología del Deporte, 23(2), 445-449. 
Flory, S. B., \& McCaughtry, N. (2014). The influences of pre-professional socialization on early career physical educators. Journal of Teaching in Physical Education, 33(1), 93-111. doi.org/10.1123/jtpe.2013-0089

Fransen, K., Decroos, S., Vande Broek, G., \& Boen, F. (2016). Leading from the top or leading from within? A comparison between coaches' and athletes' leadership as predictors of team identification, team confidence, and team cohesion. International Journal of Sports Science \& Coaching, 11, 757-771. doi.org/10.1177/1747954116676102

Funder, D. C. (1995). On the accuracy of personality judgment: A realistic approach. Psychological Review, 102(4), 652-670. doi.org/10.1037/0033-295X.102.4.652

Gian C., Karen L., \& Mark L. 2012. Knowledge sharing: Influences of trust, commitment and cost. Journal of Knowledge Management, 165, 740-753. doi.org/10.1108/13673271211262781

Goose, M., \& Winter, S. (2012). The coach's impact on long distance runners' training and competition motivation. International Journal of Sports Science \& Coaching, 7, 383-398. doi.org/10.1260/1747-9541.7.2.383

Hayes, A. F. (2009). Beyond Baron and Kenny: Statistical mediation analysis in the new millennium. Communication Monographs, 76(4), 408-420. doi.org/10.1080/03637750903310360

Hilbig, B. E., \& Zettler, I. (2009). Pillars of cooperation: Honesty-humility, social value orientations, and economic behavior. Journal of Research in Personality, 43(3), 516-519. doi.org/10.1016/j.jrp.2009.01.003 
Hülsheger, U. R., Anderson, N., \& Salgado, J. F. (2009). Team-level predictors of innovation at work: A comprehensive meta-analysis spanning three decades of research. The Journal of Applied Psychology, 94(5), 1128-1145. doi.org/10.1037/a0015978

Iso-Ahola, S. E. (1995). Intrapersonal and interpersonal factors in athletic performance. Scandinavian Journal of Medicine and Science in Sports, 5(4), 191-199. doi: 10.1111/j.1600-0838.1995.tb00035.x

Jankowski, P. J., Sandage, S. J., \& Hill, P. C. (2013). Differentiation-based models of forgivingness, mental health and social justice commitment: Mediator effects for differentiation of self and humility. Journal of Positive Psychology, 8(5), 412-424. doi.org/10.1080/17439760.2013.820337

Keegan, R., Spray, C., Harwood, C., \& Lavallee, D. (2011) From 'motivational climate' to 'motivational atmosphere': A review of research examining the social and environmental influences on athlete motivation in sport. In: Sport psychology (pp. 1-55). Hauppauge, New York: NovaScience Publications.

Kemper, T.D. (1968). Reference groups, socialization, and achievement. American Sociological Review, 33, 31-45. doi.org/10.2307/2092238

Kenny, D.A., Albright, L., Malloy, T.E., \& Kashy, D.A. (1994). Consensus in interpersonal perceptions: Acquaintance and the big five. Psychological Bulletin, 116(2), 245-258. doi.org/10.1037/0033-2909.116.2.245

Kesebir, P. (2014). A quiet ego quiets death anxiety: Humility as an existential anxiety buffer. Journal of Personality and Social Psychology, 106(4), 610-623. doi.org/10.1037/a0035814 
Kim, H.D., \& Cruz, A. (2016). The influence of coaches' leadership styles on athletes' satisfaction and team cohesion: A meta-analytic approach. International Journal of Sports Science \& Coaching, 11, 900-909. doi.org/10.1177/1747954116676117

Krause, N. (2010). Religious involvement, humility, and self-rated health. Social Indicators Research, 98(1). 23-39. doi: 10.1007/s11205-009-9514-x

Krause, N., Pargament, K. I., Hill, P. C., \& Ironson, G. (2016). Humility, stressful life events, and psychological well-being: Findings from the landmark spirituality and health survey. Journal of Positive Psychology, 11(5), 499-510. doi.org/10.1080/17439760.2015.1127991

Kruse, E., Chancellor, J., \& Lyubomirsky, S. (2017). State humility: Measurement, conceptual validation, and intrapersonal processes. Self and Identity, 16(4), 399-438. doi.org/10.1080/15298868.2016.1267662

LaBouff, J. P., Rowatt, W. C., Johnson, M. K., Tsang, J., \& Willerton, G. M. (2012). Humble persons are more helpful than less humble persons: Evidence from three studies. The Journal of Positive Psychology, 7(1), 16-29. doi.org/10.1080/17439760.2011.626787

Landrum, R.E. (2011). Measuring dispositional humility: A first approximation. Psychological Reports, 108(1), 217-228. doi.org/10.2466/02.07.09.PR0.108.1.217-228

Larsen, C. H., Alfermann, D., Henriksen, K., \& Christensen, M. K. (2013). Successful talent development in soccer: The characteristics of the environment. Sport, Exercise, and Performance Psychology, 2(3), 190-206. doi.org/10.1037/a0031958

Lee, K. \& Ashton, M. C. (2004). Psychometric properties of the HEXACO personality inventory. Multivariate Behavioral Research, 39, 329-358. doi.org/10.1207/s15327906mbr3902_8 
Leary, M. R., Tate, E. B., Adams, C. E., Allen, A. B., \& Hancock, J. (2007). Self-Compassion and reactions to unpleasant self-relevant events: The implications of treating oneself kindly. Journal of Personality and Social Psychology, 92(5), 887-904. doi.org/10.1037/0022-3514.92.5.887

MacDonald, D., Cote, J., \& Deakin. (2010). The impact of informal coach training on the personal development of youth sport athletes. International Journal of Sports Science \& Coaching, 5, 363-372. doi.org/10.1260/1747-9541.5.3.363

MacKinnon, D. P., Lockwood, C. M., \& Williams, J. (2004). Confidence limits for the indirect effect: Distribution of the product and resampling methods. Multivariate Behavioral Research, 39(1), 99-128. doi.org/10.1207/s15327906mbr3901_4

Martens, M.P., Dams-O’Connor, K., \& Beck, N.C. (2006). A systematic review of college student-athlete drinking: Prevalence rates, sport-related factors, and interventions. Journal of Substance Abuse Treatment, 31, 305-316. doi.org/10.1016/j.jsat.2006.05.004

Martin, W. E., \& Bridgmon, K. D. (2012). Quantitative and statistical research methods. From hypothesis to results. San Francisco, CA: Wiley \& Sons, Inc.

Mastroleo, N. R., Marzell, M., Turrisi, R., \& Borsari, B. (2012). Do coaches make a difference off the field? The examination of athletic coach influence on early college student drinking. Addiction Research and Theory, 20(1), 64-71.

doi:10.3109/16066359.2011.562621

McAllister, D.J. (1995). Affect- and cognition-based trust as foundations for interpersonal cooperation in organizations. Academy of Management Journal, 38(1), 24-59. doi: $10.2307 / 256727$ 
Neff, K. D., Kirkpatrick, K. L., \& Rude, S. S. (2007). Self-compassion and adaptive psychological functioning. Journal of Research in Personality, 41(1), 139-154. doi.org/10.1016/j.jrp.2006.03.004

Okhuysen, G.A., \& Bechky, B.A. 2009. Coordination in organizations: An integrative perspective. Academy of Management Annals, 3, 463-502. doi.org/10.1080/19416520903047533

Owens, B.P., \& Hekman, D.R. (2016). How does leader humility influence team performance? Exploring the mechanisms of contagion and collective promotion focus. Academy of Management Journal, 59(3), 1088-1111. doi: 10.5465/amj.2013.0660

Perez, D., Van Horn, S., \& Otten, M. (2014). Coach John Wooden's pyramid of success: A comparison to the sport psychology literature. International Journal of Sports Science \& Coaching, 9, 85-101. doi.org/10.1260/1747-9541.9.1.85

Peterson, C., \& Seligman, M.E.P. (2004). Character strengths and virtues: A handbook and classification. New York, NY: Oxford University Press.

Pirola-Merlo, A., Hartel, C., Mann, L., \& Hirst, G. (2002). How leaders influence the impact of affective events on team climate and performance in R\&D teams. The Leadership Quarterly, 13, 561-581. doi.org/10.1016/S1048-9843(02)00144-3

Pullon, S. 2008. Competence, respect and trust: Key features of successful interprofessional nurse-doctor relationships. Journal of Interprofessional Care, 22, 133-147. doi.org/10.1080/13561820701795069

Preacher, K. J., \& Hayes, A. F. (2008). Asymptotic and resampling strategies for assessing and comparing indirect effects in multiple mediator models. Behavior Research Methods, 40(3), 879-891. doi.org/10.3758/BRM.40.3.879 
Preacher, K. J., \& Hayes, A. F. (2004). SPSS and SAS procedures for estimating indirect effects in simple mediation models. Behavior Research Methods, Instruments, and Computers, 36(4), 717-731. doi.org/10.3758/BF03206553

Riyanto, Y. E., \& Zhang, J. (2014). An egalitarian system breeds generosity: The impact of redistribution procedures on pro-social behavior. Economic Inquiry, 52(3), 1027-1039. doi:10.1111/ecin.12090

Rottensteiner, C., Laakso, L., Pihlaja, T., Konttinen, N. (2013). Personal reasons for withdrawal from team sports and the influence of significant others among youth athletes. International Journal of Sports Science \& Coaching, 8, 19-32. doi.org/10.1260/17479541.8.1.19

Rowatt, W. C., Powers, C., Targhetta, V., Comer, J., Kennedy, S., \& Labouff, J. (2006). Development and initial validation of an implicit measure of humility relative to arrogance. The Journal of Positive Psychology, 1(4), 198-211.

Ruberton, P.M., Huynh, H.P., Miller, T.A., Kruse, E., Chancellor, J., \& Lyubomirsky, S. (2016). The relationship between physician humility, physician-patient communication, and patient health. Patient Education and Counseling, 99(7), 1138-1145. doi.org/10.1016/j.pec.2016.01.012

Schaubroeck, J., Lam, S. S. K., \& Peng, A. C. 2011. Cognition-based and affect-based trust as mediators of leader behavior influences on team performance. Journal of Applied Psychology, 96(4), 863-871. doi.org/10.1037/a0022625

Shepherd, S., \& Belicki, K. (2008). Trait forgiveness and traitedness within the HEXACO model of personality. Personality and Individual Differences, 45(5), 389-394. doi.org/10.1016/j.paid.2008.05.011 
Smith, R. E., Smoll, F. L., \& Cumming, S. P. (2007). Effects of a motivational climate intervention for coaches on young athletes' sport performance anxiety. Journal of Sport and Exercise Psychology, 29(1), 39-59. doi.org/10.1123/jsep.29.1.39

Snyder, E. E. (1972). High school athletes and their coaches: Educational plans and advice. Sociology of Education, 45(3), 313-325. doi:10.2307/2112151

Somech, A., \& Drach-Zahavy, A. (2011). Translating team creativity to innovation implementation: The role of team composition and climate for innovation. Journal of Management, 39(3), 684-708. doi.org/10.1177/0149206310394187

Stangor, C., \& Thompson, E. P. (2002). Needs for cognitive economy and self-enhancement as unique predictors of intergroup attitudes. European Journal of Social Psychology, 32(4), 563-575. doi:10.1002/ejsp.114

Stellar, J. E., Gordon, A. M., Piff, P. K., Cordaro, D., Anderson, C. L., Bai, Y., Maruskin, L. A., $\&$ Keltner, D. (2017). Self-transcendent emotions and their social functions: Compassion, gratitude, and awe bind us to others through prosociality. Emotion Review, 9(3), 200-207. doi: $10.1177 / 1754073916684557$

Tabachnick, D. B., \& Fidell, L.S. (2007). Using multivariate statistics $\left(5^{\text {th }}\right.$ ed.). Boston, MA: Pearson Allyn \& Bacon.

Tangney, J.P. (2000). Humility: Theoretical perspectives, empirical findings and directions for future research. Journal of Social and Clinical Psychology, 19(1), 70-82. doi.org/10.1521/jscp.2000.19.1.70

Turman, P. D. (2003). Coaches and cohesion: The impact of coaching techniques on team cohesion in the small group sport setting. Journal of Sport Behavior, 26(1), 86-103. 
Weathington, B. L., Alexander, A. C., \& Rodebaugh, L. L. (2010). Coaching influences on student-athlete motivation, stress, and skill. Athletic Insight, 12(2), 1-18.

Williams, M. (2007). Building genuine trust through interpersonal emotion management: A threat regulation model of trust and collaboration across boundaries. Academy of Management Review, 32: 595-621. doi:10.5465/AMR.2007.24351867

Wright, J., Nadelhoffer, T., Perini, T., Langville, A., Echols, M., \& Venezia, K. (2016). The psychological significance of humility. The Journal of Positive Psychology 12(1), 3-12. doi.org/10.1080/17439760.2016.1167940 
HUMBLE COACHES

Table 1

Bivariate Correlations of Variables of Interest

\begin{tabular}{|c|c|c|c|c|c|c|c|}
\hline Variables & 1 & 2 & 3 & 4 & 5 & 6 & 7 \\
\hline 1. Humility & - & & & & & & \\
\hline 2. Affect-Trust & $.73^{* * *}$ & - & & & & & \\
\hline 3. Cognition-Trust & $.66^{* * *}$ & $.80^{* * * *}$ & - & & & & \\
\hline 4. Overall Influence & $.54^{* * *}$ & $.62^{* * * *}$ & $.58^{* * *}$ & - & & & \\
\hline 5. Relationship Length & $.22^{* *}$ & $.26^{* *}$ & $.23^{* *}$ & $.25^{* *}$ & - & & \\
\hline 6. Team Success & $.23^{* *}$ & $.32^{* * * *}$ & $.39^{* * *}$ & $.42^{* * *}$ & $.17^{*}$ & - & \\
\hline 7. Team Climate & $.30^{* * *}$ & $.47^{* * *}$ & $.41^{* * *}$ & $.36^{* * *}$ & $.26^{* *}$ & $.50^{* *}$ & - \\
\hline
\end{tabular}

Note: $* p<.05 .,{ }^{* *} p<.01 .,{ }^{* * *} p<.001$ 


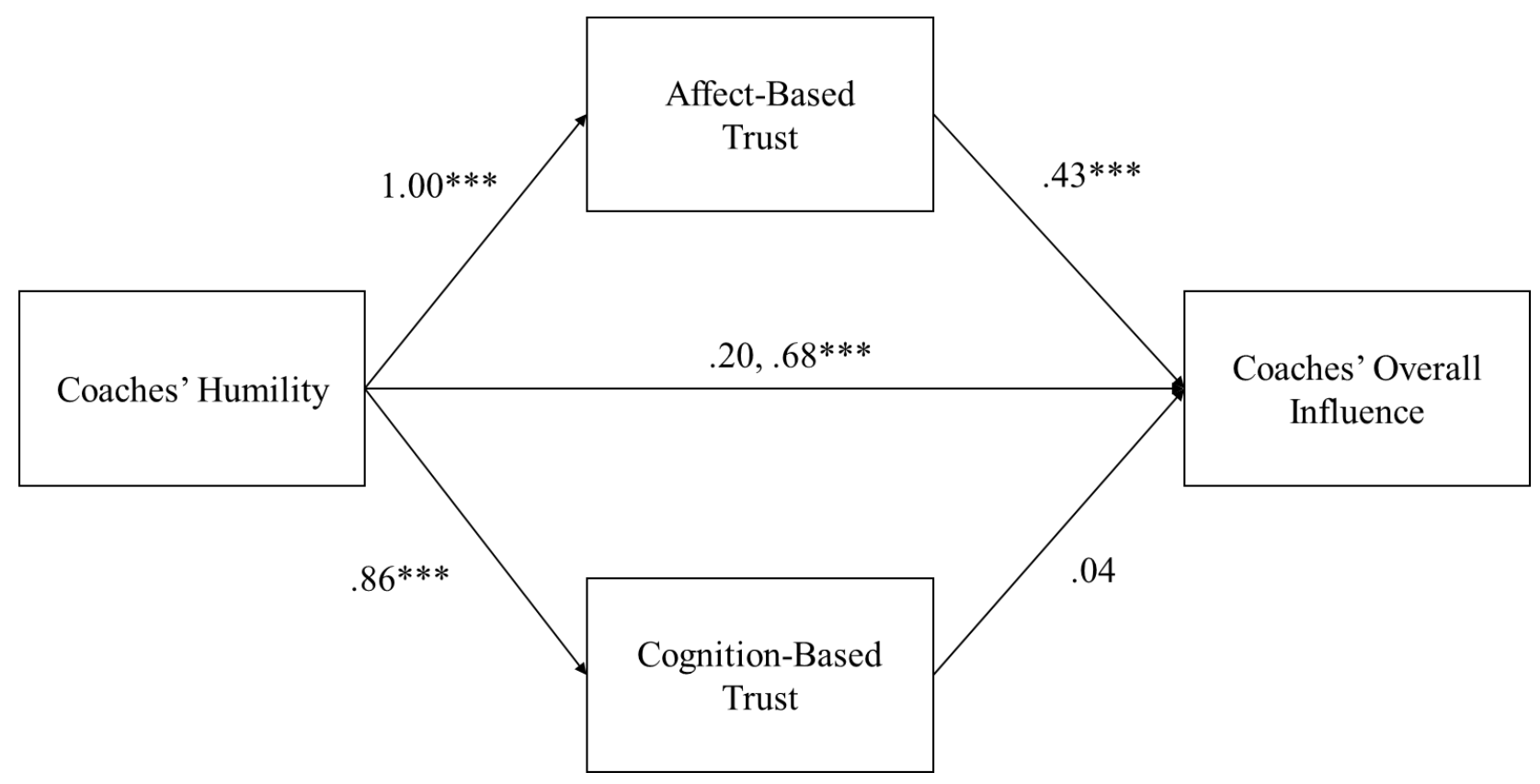

Figure 1. Indirect effect of coaches' humility on their overall influence through affect-based (and not cognition-based) trust.

Note: $* * * p<.001$ 


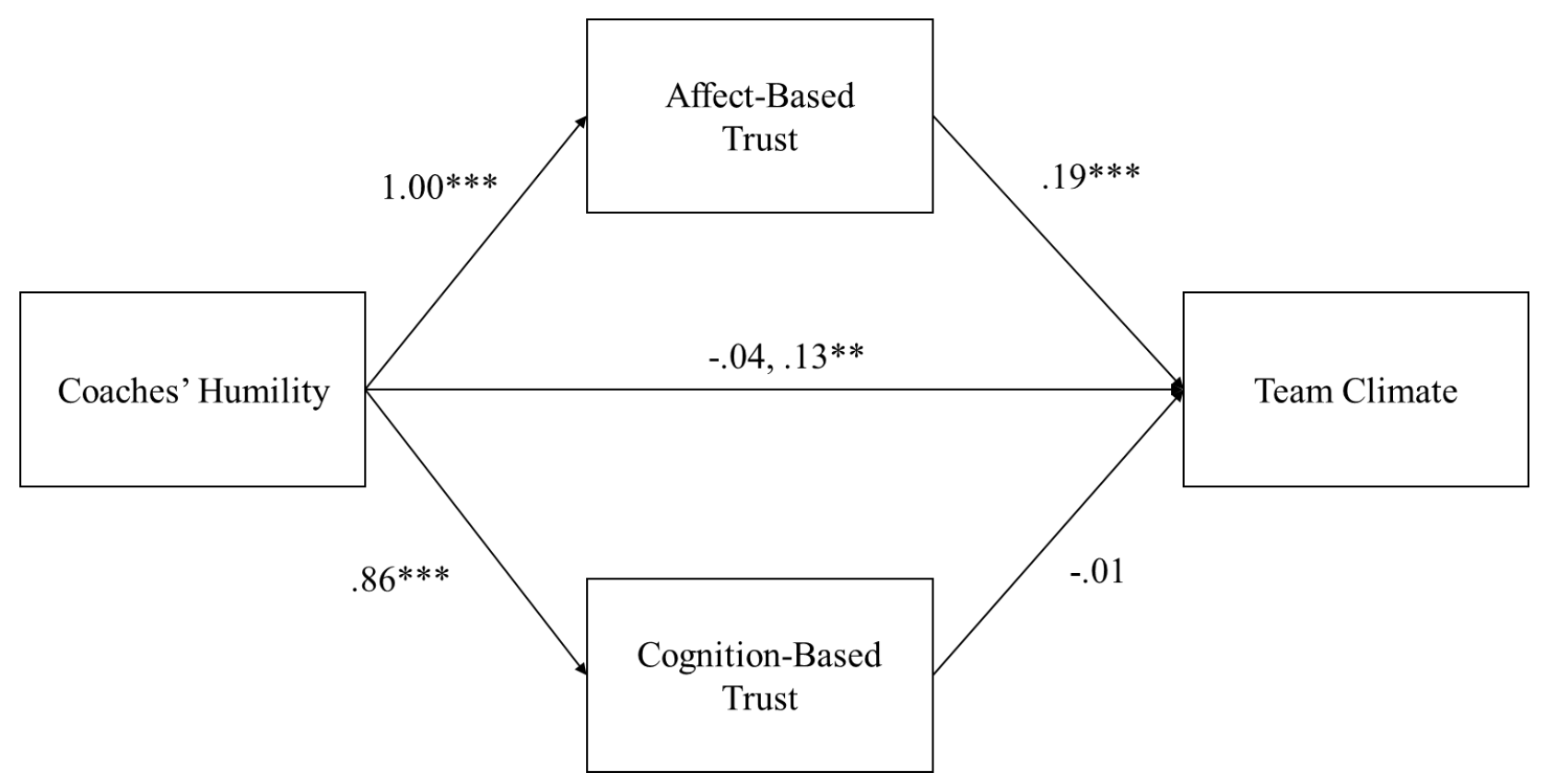

Figure 2. Indirect effect of coaches' humility on team climate through affect-based (and not cognition-based) trust.

Note: $* * * p<.001, * * p<.01$ 